\title{
Factors associated with Leishmania infection in dogs and geospatial analysis in the Sertão of Paraíba, Northeast Brazil
}

\author{
Fatores associados à infecção por Leishmania em cães e análise espacial no \\ Sertão da Paraíba, Nordeste do Brasil
}

Beatriz Maria de Almeida Braz* (D); Denny Parente de Sá Barreto Maia Leite; Raizza Barros Sousa Silva; Maria Luana Cristiny Rodrigues da Silva; Ana Clara de França Silva Azevedo"; Erotides Martins Filho'; Walter Massa Ramalho²; Marcia Almeida de Melo'

${ }^{1}$ Laboratório de Biologia Molecular do Semiárido, Programa de Pós-graduação em Ciência e Saúde Animal, Universidade Federal de Campina Grande - UFCG, Patos, PB, Brasil

${ }^{2}$ Universidade de Brasília, UNB - Campus Ceilândia, Brasília, DF, Brasil

How to cite: Braz BMA, Leite DPSBM, Silva RBS, Silva MLCR, Azevedo ACFS, Martins Filho E, et al. Factors associated with Leishmania infection in dogs and geospatial analysis in the Sertão of Paraíba, Northeast Brazil. Braz J Vet Parasitol 2021; 30(2): e023620. https://doi.org/10.1590/S1984-29612021047

\begin{abstract}
Visceral leishmaniasis (VL) is a zoonosis with a worldwide distribution that has a major impact on public health. The aim of this study was to verify the prevalence of canine infection by Leishmania infantum, the factors associated with the infection and its spatial distribution in the municipality of Mãe D'Água, in the Sertão region of Paraíba State, Northeast Brazil. Blood samples were collected from 150 dogs for diagnosis by the DPP®, ELISA-S7®, ELISA-EIE® and qPCR assays. The prevalence was calculated considering the positivity in at least two tests. SaTScan ${ }^{\circledR}$ was used for spatial analysis. The prevalence of canine infection with Leishmania was 18.6\% (28/150), with the rural area being identified as a risk factor (Odds Ratio $(O R)=2.93$ ). The permanence of the dog loose during the night $(O R=0.33)$ and deworming $(O R=0.30)$ were identified as protective factors. A risk cluster was formed in the northern region of the urban area. Mãe D'Água showed a pattern of active transmission in the rural area, but VL control measures also need to be carried out in the urban area to prevent human cases and the spread of the disease in the risk zone.
\end{abstract}

Keywords: Cluster, georeferencing, leishmaniasis, real-time PCR, serology.

\begin{abstract}
Resumo
A leishmaniose visceral (LV) é uma zoonose com distribuição mundial de grande impacto na saúde pública. O objetivo deste estudo foi verificar a prevalência da infecção canina por Leishmania infantum, os fatores associados à infecção e sua distribuição espacial no município de Mãe D'Água, na região do Sertão da Paraíba, Nordeste do Brasil. Amostras de sangue foram coletadas de 150 cães para diagnóstico pelos ensaios DPP ${ }^{\circledR}$, ELISA-S7 ${ }^{\circledR}$, ELISA-EIE® e qPCR. A prevalência foi calculada considerando-se a positividade em pelo menos dois testes. 0 SaTScan ${ }^{\circledR}$ foi utilizado para a análise espacial. A prevalência da infecção canina com Leishmania foi de 18,6\% (28/150), sendo a zona rural identificada como fator de risco (Odds Ratio $(O R)=2,93$ ). A permanência do cão solto durante a noite $(O R=0,33)$ e a vermifugação $(O R=0,30)$ foram classificadas como fatores de proteção. Um cluster de risco foi formado na região Norte da área urbana. Mãe D'Água apresentou um padrão de transmissão ativa na área rural, porém medidas de controle da LVC também precisam ser realizadas na área urbana para evitar casos humanos e a dispersão da doença na zona de risco.
\end{abstract}

Palavras-chave: Cluster, georreferenciamento, leishmaniose, PCR em Tempo Real, sorologia.

Received November 16, 2020. Accepted April 12, 2021.

*Corresponding authors: Beatriz Maria de Almeida Braz; Marcia Almeida de Melo. E-mails: beatrizbraz89@hotmail.com; marcia.melo@ufcg.edu.br 


\section{Introduction}

Visceral leishmaniasis (VL) is distributed worldwide and has a great impact on public health. The World Health Organization (2018) estimated that the global VL case count in 2018 increased from 50,000 to 90,000, with most of cases in Brazil, Eastern Africa, and Southeast Asia.

In Brazil, the disease is known as "kala-azar" and, currently, occurs in the five regions of the country, encompassing 19 states, in which 10,063 cases were reported from 2015 to 2017. According to Sousa et al. (2018), most of the cases were reported in the Northeast region, especially in the states of Maranhão and Ceará.

In Brazil, the transmission occurs mainly through the blood repast of infected females of the Lutzomyia longipalpis phlebotomine (Lainson \& Rangel, 2005; Missawa \& Lima, 2006) and, rarely by means of either blood transfusion (Cohen et al., 1991) or via the trans-placental route. In the wild, coyotes and foxes (Dusicyon vetulus and Cerdocyon thous) act as reservoirs, and in the domestic environment, dogs preserve the transmission cycle (World Health Organization, 2014), thereby acting as important sources of infection for the disease vectors (Ashford, 1996); humans are accidental hosts of the parasite.

The Brasil (2011) proposes the use of the DPP $®$ rapid test and ELISA EIE-LVC $®$ as screening and confirmatory tests, respectively, for the diagnosis Leishmania infection in dogs. When the animal is positive, treatment is only possible after obtaining the responsible guardian's permission and with drugs that are not used in humans, such as Milteforan, a miltefosine-based medicine, registered with the Ministry of Agriculture, Livestock and Supply (MAPA). However, the use of Milteforan is an individual protection measure for the dog and is not used as a public health measure to control the disease. (Brasil, 2016). In Brazil, based on an analysis of the local epidemiological situation, the Visceral Leishmaniasis Control Program (PCLV) suggests that preventive and control measures should be adopted to tackle this zoonosis. These measures consist of entomological surveillance, treatment of human cases, confirmation, and the culling of positive dogs (Brasil, 2006); however, it is questioned whether the latter measure can spread of the infection (Werneck, 2014).

The prevalence of Leishmania infection in dogs is itself a risk indicator for its occurrence in humans, and its study indicates to the local surveillance agencies the control actions to be implemented. Although the Ministry of Health indicates the serological survey as a surveillance measure, over the last decades the action has not been carried out by health surveillance services in the states and municipalities. Numerous studies have been conducted by the scientific community in the states of the Northeast region, such as Rio Grande do Norte (Amóra et al., 2006), Maranhão (Barbosa et al., 2010), Piauí (Figueiredo et al., 2017), Ceará (Rodrigues et al., 2017), and Paraíba (Brito et al., 2016; Fernandes et al., 2018; Silva et al., 2018); these studies have emphasized the prevalence of infection with Leishmania.

Three cases of human visceral leishmaniasis (HVL) were reported between 2014 and 2018 in the municipality of Mãe D'Água in the state of Paraíba (Sinan, 2019); a new case was reported in December 2019, but it has still not been logged in the national disease notification system (SINAN). As a result, a serological survey was conducted in the municipality on 55 stray dogs by the endemic disease control agents and tested at the Central Laboratory of Public Health of Paraíba (LACEN), as recommended by the Ministry of Health, and the occurrence of positive animals was $10.9 \%(6 / 55)$.

Mãe D'Água is situated in the Sertão mesoregion of Paraíba state, in the metropolitan region of the municipality of Patos. The preserved xerophytic caatinga vegetation is set in a relief denominated "Sertanejo Plain," which constitutes an extensive pediplain surface. This surface is formed by a set of elongated and aligned mountains over the regional geological structure, which extends through the municipalities of Manaíra to Teixeira. Located in this region is the Jabre Peak, with an altitude of $1,197 \mathrm{~m}$, which constitutes the highest point of the state (Beltrão et al., 2005). According to Silva et al. (2017a), the Caatinga is a well-recognized ecological region that lies in the semiarid hinterland of northeastern Brazil and that covers $912,529 \mathrm{~km}^{2}$ and refers mostly to a seasonally dry tropical forest (SDTF) that presents a mosaic of different physiognomies. This type of biome favors the occurrence of vector (Lutzomyia longipalpis) throughout the year as well as maintenance of the disease cycle.

In view of this, the aim of this study was to analyze the prevalence of canine infection by Leishmania in the municipality of Mãe D'Água, to study the epidemiology of the zoonosis by analyzing the associated factors, and to verify the spatial distribution of the disease using georeferencing. The results will allow us to identify priority areas and disease patterns, so that adequate prevention and control measures are implemented in the future. 


\section{Material and Methods}

\section{Study design and setting}

The study was conducted in the urban and rural areas of the municipality of Mãe D'Água ( $7^{\circ} 15^{\prime} 10^{\prime \prime} S, 37^{\circ} 25^{\prime} 58^{\prime \prime} \mathrm{W}$ ), located in the semi-arid region of Paraíba State, in the Sertão mesoregion (Figure 1). The area has a hot and dry climate and high temperatures throughout the year, with annual variations between $23{ }^{\circ} \mathrm{C}$ and $30^{\circ} \mathrm{C}$, with the average rainfall in 2018 of $746.9 \mathrm{~mm}$ (AESA, 2019) (Köppen climatic classification: BSh). The estimated population is 4,019 inhabitants spread over $243.75 \mathrm{~km}^{2}, 1,569$ and 2,450 of whom live in the urban and rural areas, respectively (IBGE, 2020). The municipality does not have a territorial division of neighborhoods, and the central neighborhood is considered the urban area.

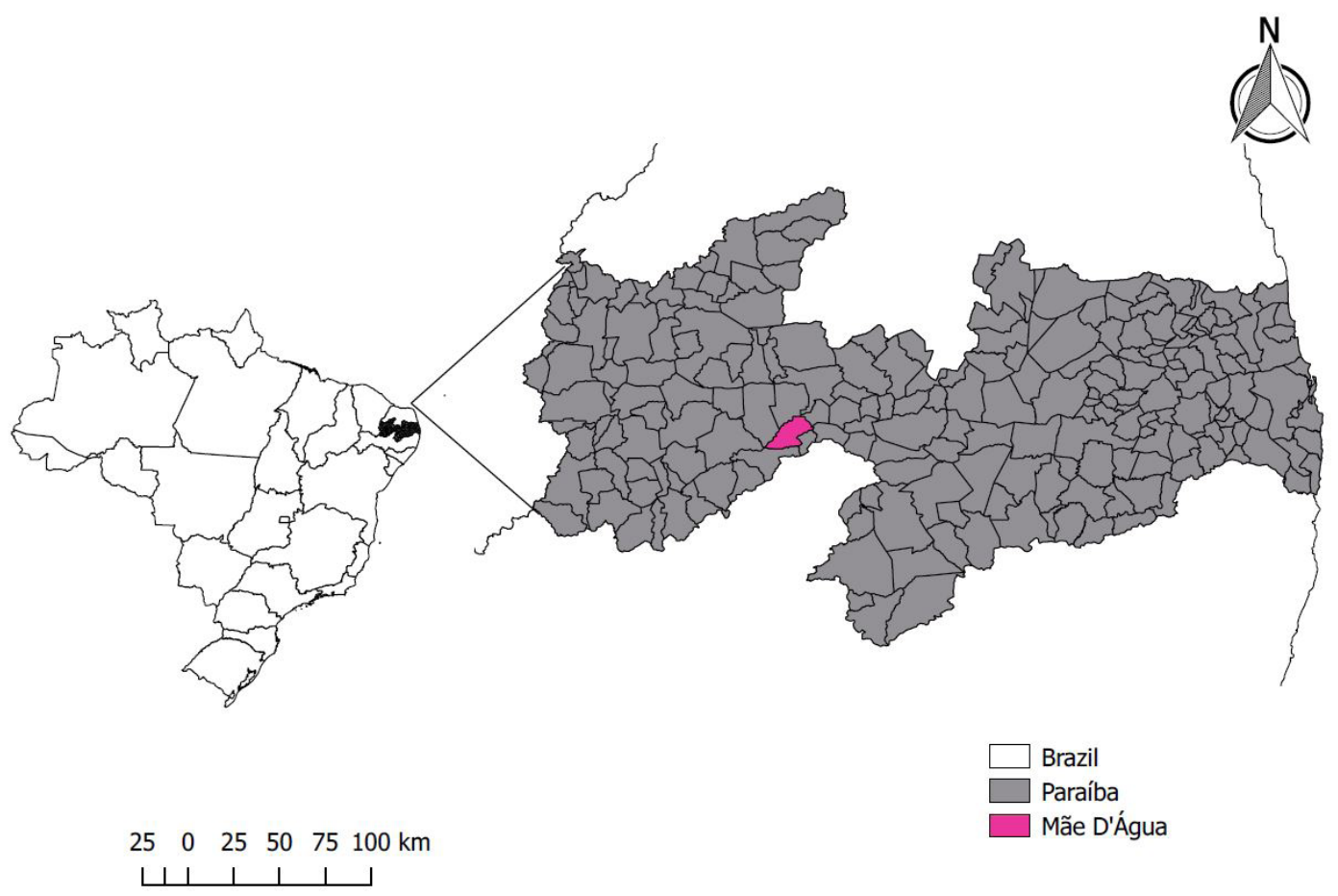

Figure 1. Map of the municipality of Mãe D’Água, Semi-arid region of Paraíba State, Brazil, 2018.

\section{Ethical considerations}

The work was approved by the Ethics Committee of the Health and Rural Technology Center (CSTR) of the Federal University of Campina Grande (UFCG), under protocol n. 156 059/2018.

\section{Sample size}

Based on methodology of Savani et al. (2003) and take into consideration that there is one dog for every seven inhabitants, the estimated canine population of the municipality was 574 animals. Using the simple random sampling formula, with an expected prevalence of 50\%, a 99\% significance level, and a sampling error of 5\% (Thrusfield, 2007), the minimum estimated sample size was 146 animals.

\section{Sample and data collection}

The samples were collected from May to June 2018, in the urban and rural locations, and in points chosen using the municipality sketch. Home visits were carried out with the support of healthcare and endemic disease agents of the Municipal Healthcare Department. Blood samples were collected from 150 male and female domestic dogs (75 each from the urban and rural areas) over 6 months old. The samples were collected by jugular, cephalic, or 
saphenous venipuncture, using $5-\mathrm{mL}$ sterile syringes and $25 \times 8 \mathrm{~mm}$ needles, added to tubes containing $4 \%$ sodium citrate, refrigerated in a thermal box, and forwarded to the Semi-arid Molecular Biology Laboratory (BiolMol/UFCG), Patos Campus, Paraíba. Plasma and whole blood samples were used for serological and molecular diagnosis, respectively. The samples were aliquoted in $1.5 \mathrm{ml}$ microtubes, identified and stored at $-20^{\circ} \mathrm{C}$ until the exams were performed.

The guardians answered an epidemiological survey containing 31 variables related to the guardian, the animal, and the environment where the animal lives, aiming to identify epidemiological indicators associated with the occurrence of the disease.

\section{Serological tests}

The prevalence of canine infection by Leishmania was estimated by the immunochromatographic Dual Path Platform DPP ${ }^{\circledR}$ (Rapid Test Canine Visceral Leishmaniasis, Bio-Manguinhos, Rio de Janeiro, Brasil), and two enzymelinked immunosorbent assays (ELISA-EIE ${ }^{\circledR}$, Canine Visceral Leishmaniasis, Bio-Manguinhos, Rio de Janeiro, Brazil; ELISA-S7 ${ }^{\circledR}$ kit, Biogene Industry and Commerce Ltda, Recife/PE, Brazil) and the analyses were carried out by the team of the Municipal Laboratory of Patos/PB and of the Semi-arid Molecular Biology Laboratory (UFCG), respectively. The protocol followed the manufacturers' recommendations. The samples that reacted in the DPP $®$ were sent to the Public Health Central Laboratory of Paraíba (LACEN), which is responsible for conducting the ELISA- EIE ${ }^{\circledR}$ test. As proposed by the Ministry of Health, only the positive samples in the DPP® were tested in the ELISA kit EIE-CVL ${ }^{\circledR}$ (Canine Visceral Leishmaniasis).

\section{Real-time quantitative polymerase chain reaction (qPCR)}

The DNA of the blood samples were extracted using U-Trinzol ${ }^{\circledR}$, following the manufacturer's recommendations and qPCR was performed as previously described (Fernandes et al., 2018). Leishmania infantum culture was used as a positive control and ultra-pure water as a negative control. The primers used for the amplification of minicircle DNA sequences from the kinetoplast (kDNA) of L. infantum were Leish RV1 (5'-CTT TTCTGGTCCCGCGGGTAGG-3') and Leish RV2 (5'-CCACCCGGCCTATTTTACACCA-3'). Thermocycling was conducted using a Bioer Technology ${ }^{\circledR}$ thermocycler. The prevalence was determined taking into consideration the positivity in at least two serological techniques or only in PCR.

\section{Statistical analysis}

The analysis of the risk factors associated with infection was calculated in two stages using univariate and multiple analysis, and the independent variables were categorized and codified. The categories income, level of schooling, cleaning frequency, and types of vaccine were aggregated to facilitate the statistical analysis due to the small sample size. Either chi-squared or Fisher's exact tests (Zar, 1999) were used in the univariate analysis; the variables with $p \leq 0.20$ multiple analysis were carried out by multiple logistic regression (Bruce \& Bruce, 2017; Fávero et al., 2009; James et al., 2014; Hosmer \& Lemeshow, 2000). The significance level adopted in the multiple analysis was $5 \%$. The analysis was carried out with IBM SPSS ${ }^{\circledR}$ Statistics for Windows, version 22.0 (IBM Corp., Armonk, USA).

\section{Georeferencing}

The geographical coordinates of each animal's residence were obtained using the Garmin eTrex 30 receiver global positioning system (GPS) during the application of the questionnaire with the guardians of the dogs. Using the obtained geographic coordinates, the cases were inserted into the cartographic base of the municipality (Figure 3), using a geographic information system (GIS) and Google Earth 7.3.0; the maps were created in quantum GIS (QGIS). A heatmap or quadratic Kernel estimation was constructed using QGIS 2.18.0 software to observe the disease clusters. SaTScan ${ }^{\circledR}$ software was used to verify the areas with cases exceeding the expected number, by means of scan statistics for the detection of clusters, using a Bernoulli model (Gatrell et al., 1996; Levine, 2017).

\section{Results}

As proposed by the Ministry of Health, only the positive samples in the DPP $(19.3 \%$; 29/150) were tested in the ELISA kit EIE-CVL $®$, resulting in $12.6 \%$ (19/29) of Leishmania infection. 
Of the 150 serum samples analyzed, 19.3\% (29/150), 41.3\% (62/150), and 3.3\% (5/150) tested positive in the DPP ${ }^{\circledR}$ screening test, ELISA-S7 ${ }^{\circledR}$, and $\mathrm{APCR}$, respectively.

Considering as positive criteria animals that were reactive in at least two serological tests or only in qPCR, the prevalence of Leishmania infection in dogs in the municipality of Mãe D'Água was 18.6\% (28/150) with 10.6\% (8/75) and $26.6 \%(20 / 75)$ from urban and rural areas, respectively. In the univariate analysis, the variables with a p-value $\leq 0.2$ (Table 1) were: origin, income, gender, breed, type of rearing, feeding, contact with wild animals, contact with felines and birds, rearing environment, cleanliness, frequency of cleaning, deworming, whether the dog was adopted, hunting activity, where the dog sleeps, and how does if spend the night (loose or fastened on a leash).

Table 1. Univariate analysis of the risk factors associated with canine visceral leishmaniasis in the Municipality of Mãe D'Água, Semi-arid region of Paraíba State, between May and July 2018. Significant variables in the univariate analysis ( $p \leq 0.2)$.

\begin{tabular}{|c|c|c|c|c|c|c|}
\hline Variable & Category & N. of animals & Positives & Odds ratio & $\begin{array}{c}\text { Confidence } \\
\text { interval }\end{array}$ & P-value \\
\hline \multirow[t]{2}{*}{ Origin } & Urban & 75 & $8(10.6 \%)$ & & & \\
\hline & Rural & 75 & $20(26.6 \%)$ & 3.04 & $1.28-7.84$ & $0.01 *$ \\
\hline \multirow{2}{*}{$\begin{array}{l}\text { Level of schooling } \\
\text { of the owner }\end{array}$} & Illiterate & 12 & $3(25 \%)$ & & & \\
\hline & Any form of literacy & 138 & $25(18.1 \%)$ & 0.66 & $0.18-3.14$ & 0.55 \\
\hline \multirow{2}{*}{$\begin{array}{c}\text { Income of the } \\
\text { owner }\end{array}$} & Less than $2 \mathrm{MS}$ & 91 & $14(15.3 \%)$ & & & \\
\hline & 2 or $>2 \mathrm{MS}$ & 59 & $14(23.7 \%)$ & 1.71 & $0.74-3.94$ & $0.20 *$ \\
\hline \multirow{2}{*}{$\begin{array}{l}\text { Gender of the } \\
\text { animal }\end{array}$} & Male & 105 & $25(23.8 \%)$ & & & \\
\hline & Female & 45 & $3(6.6 \%)$ & 0.22 & $0.05-0.70$ & $0.02 *$ \\
\hline \multirow[t]{2}{*}{ Age of the animal } & 6 months - 2 years & 17 & $4(23.5 \%)$ & & & \\
\hline & $>2$ Years & 133 & $24(18 \%)$ & 0.71 & $0.22-2.71$ & 0.58 \\
\hline \multirow[t]{2}{*}{ Breed } & Mixed breed & 132 & $27(20.4 \%)$ & & & \\
\hline & Pure breed & 18 & $1(5.5 \%)$ & 0.22 & $0.01-1.19$ & $0.16 *$ \\
\hline \multirow[t]{3}{*}{ Type of rearing } & Domiciliary & 70 & $7(10 \%)$ & & & \\
\hline & Semi-domiciliary & 62 & $17(27.4 \%)$ & 3.4 & $1.34-9.42$ & 0.01 * \\
\hline & Free & 18 & $4(22.2 \%)$ & 2.57 & $1.60-9.79$ & $0.17 *$ \\
\hline \multirow[t]{3}{*}{ Type of feed } & Commercial feed & 13 & $1(7.7 \%)$ & & & \\
\hline & Homemade food & 125 & $26(20.8 \%)$ & 3.15 & $0.57-58.71$ & $0.28 *$ \\
\hline & Both & 12 & $1(8.3 \%)$ & & & \\
\hline \multirow{2}{*}{$\begin{array}{c}\text { Contact with other } \\
\text { animals }\end{array}$} & Yes & 125 & $26(20.8 \%)$ & 3.02 & $0.81-19.57$ & $0.15^{*}$ \\
\hline & No & 25 & $2(8 \%)$ & & & \\
\hline \multirow{2}{*}{$\begin{array}{l}\text { Contact with } \\
\text { equines }\end{array}$} & Yes & 12 & $3(25 \%)$ & 1.50 & $0.31-5.47$ & 0.55 \\
\hline & No & 138 & $25(18.1 \%)$ & & & \\
\hline \multirow{2}{*}{$\begin{array}{c}\text { Contact with wild } \\
\text { animals }\end{array}$} & Yes & 20 & $2(10 \%)$ & 0.44 & $0.06-1.67$ & $0.29 *$ \\
\hline & No & 130 & $26(20 \%)$ & & & \\
\hline \multirow{2}{*}{$\begin{array}{l}\text { Contact with } \\
\text { felines }\end{array}$} & Yes & 38 & $10(26.3 \%)$ & 1.86 & $0.75-4.4$ & $0.16 *$ \\
\hline & No & 112 & $18(16 \%)$ & & & \\
\hline \multirow[t]{2}{*}{ Contact with dogs } & Yes & 85 & $17(20 \%)$ & 1.22 & $0.53-2.90$ & 0.63 \\
\hline & No & 65 & $11(17 \%)$ & & & \\
\hline \multirow{2}{*}{$\begin{array}{l}\text { Contact with } \\
\text { swines }\end{array}$} & Yes & 17 & $2(11.7 \%)$ & 0.54 & $0.08-2.11$ & 0.44 \\
\hline & No & 133 & $26(19.5 \%)$ & & & \\
\hline \multirow{2}{*}{$\begin{array}{l}\text { Contact with small } \\
\text { ruminants }\end{array}$} & Yes & 15 & $3(20 \%)$ & 1.1 & $0.23-3.78$ & 0.88 \\
\hline & No & 135 & $25(18.5 \%)$ & & & \\
\hline \multirow{2}{*}{$\begin{array}{l}\text { Contact with } \\
\text { bovines }\end{array}$} & Yes & 15 & $4(26.6 \%)$ & 1.68 & $0.43-5.40$ & 0.40 \\
\hline & No & 135 & $24(17.7 \%)$ & & & \\
\hline \multirow[t]{2}{*}{ Contact with birds } & Yes & 84 & $21(25 \%)$ & 2.80 & $1.15-7.57$ & $0.02 *$ \\
\hline & No & 66 & $7(10.6 \%)$ & & & \\
\hline \multirow{2}{*}{$\begin{array}{l}\text { In which } \\
\text { environment is } \\
\text { reared }\end{array}$} & Soil & 93 & $21(22.5 \%)$ & 0.20 & $0.17-0.46$ & $0.12^{*}$ \\
\hline & Cement & 57 & $7(12.2 \%)$ & & & \\
\hline \multirow{2}{*}{$\begin{array}{l}\text { Execution of the } \\
\text { cleansing of the } \\
\text { environment }\end{array}$} & Yes & 89 & $12(13.4 \%)$ & 0.43 & $0.18-1.00$ & $0.05 *$ \\
\hline & No & 61 & $16(26.2 \%)$ & & & \\
\hline Variable & Category & N. of animals & Positives & Odds ratio & Confidence interval & P-value \\
\hline
\end{tabular}


Table 1. Continued...

\begin{tabular}{|c|c|c|c|c|c|c|}
\hline Variable & Category & N. of animals & Positives & Odds ratio & $\begin{array}{c}\text { Confidence } \\
\text { interval }\end{array}$ & P-value \\
\hline \multirow{3}{*}{$\begin{array}{l}\text { Cleaning of the } \\
\text { environment } \\
\text { frequency }\end{array}$} & Does not perform & 61 & $16(26.2 \%)$ & & & \\
\hline & Daily & 63 & $8(12.6 \%)$ & 0.40 & $0.15-1.01$ & $0.06^{*}$ \\
\hline & $\begin{array}{l}\text { Weekly/Fortnightly/ } \\
\text { monthly }\end{array}$ & 26 & $4(15.3 \%)$ & 0.51 & $0.13-1.59$ & $0.27 *$ \\
\hline \multirow{2}{*}{$\begin{array}{l}\text { Vaccinated animal } \\
\text { (Anti-rabies, } \\
\text { viruses, CVL) }\end{array}$} & Yes & 126 & $22(17.4 \%)$ & & & \\
\hline & No & 24 & $6(25 \%)$ & 0.33 & $0.12-0.79$ & 0.38 \\
\hline \multirow{2}{*}{$\begin{array}{l}\text { Vermifugated } \\
\text { animal }\end{array}$} & Yes & 70 & $7(10 \%)$ & 0.31 & $0.11-0.75$ & $0.01 *$ \\
\hline & No & 80 & $21(26.2 \%)$ & & & \\
\hline \multirow{2}{*}{ Presence of ticks } & Yes & 115 & $21(18.2 \%)$ & 0.89 & $0.35-2.46$ & 0.81 \\
\hline & No & 35 & $7(20 \%)$ & & & \\
\hline \multirow{2}{*}{$\begin{array}{l}\text { Has Always lived } \\
\text { with the same } \\
\text { owner }\end{array}$} & Yes & 98 & $18(18.3 \%)$ & 0.94 & $0.40-2.29$ & 0.89 \\
\hline & No & 52 & $10(2 \%)$ & & & \\
\hline \multirow[t]{3}{*}{ Adopted } & No & 86 & $14(16.2 \%)$ & & & \\
\hline & From the streets & 15 & $2(13.3 \%)$ & 0.79 & $0.11-3.30$ & 0.77 \\
\hline & Other owner & 49 & $12(24.4 \%)$ & 1.66 & $1.69-3.97$ & $0.24^{*}$ \\
\hline \multirow{2}{*}{$\begin{array}{l}\text { Has Always lived } \\
\text { in the same } \\
\text { municipality }\end{array}$} & Yes & 125 & $25(20 \%)$ & 1.83 & $0.57-8.17$ & 0.35 \\
\hline & No & 25 & $3(12 \%)$ & & & \\
\hline \multirow[t]{2}{*}{ The animal hunts } & Yes & 18 & $6(33.3 \%)$ & 2.5 & $0.79-7.19$ & $0.09 *$ \\
\hline & No & 132 & $22(16.6 \%)$ & & & \\
\hline \multirow{3}{*}{$\begin{array}{l}\text { Where does it } \\
\text { sleep }\end{array}$} & Indoors & 42 & $5(11.9 \%)$ & & & \\
\hline & Peridomicile & 98 & $21(21.4 \%)$ & 2.01 & $0.75-6.41$ & $0.19 *$ \\
\hline & Street & 10 & $2(20 \%)$ & 1.85 & $0.23-10.46$ & 0.50 \\
\hline \multirow{2}{*}{$\begin{array}{c}\text { How spends the } \\
\text { night }\end{array}$} & Free/without collar & 90 & $11(12.2 \%)$ & 0.39 & $0.21-0.68$ & $0.01 *$ \\
\hline & Tied & 60 & $17(28.3 \%)$ & & & \\
\hline \multirow[t]{2}{*}{ Travels } & Yes & 12 & $2(16.6 \%)$ & 0.86 & $0.12-3.52$ & 0.86 \\
\hline & No & 138 & $26(18.8 \%)$ & & & \\
\hline \multirow[t]{2}{*}{ Repellent collar } & Yes & 1 & - & 7.51 & $0,00-0,00$ & 0.99 \\
\hline & No & 149 & $28(18.8 \%)$ & & & \\
\hline
\end{tabular}

The categories that remained at the end of the multiple logistic regression model were the following: animals that stay loose at night without restraint by leashes $(O D=0.33)$ and deworming (the animal has been dewormed at least once) $(\mathrm{OD}=0.30)$. These categories were identified as protection factors for the occurrence of $\mathrm{CVL}$ and rural origin was identified as a risk factor $(O D=2.93)$ (Table 2). Dogs from the rural area were 2.93 times more likely to contract the disease. Dogs that were loose (not fastened on a leash at night) and dewormed were $67 \%$ and $70 \%$ more protected, respectively, than the others.

Table 2. Multiple analysis of the risk and protection factors associated to canine visceral leishmaniasis in the municipality of Mãe D’Água, Semi-arid region of Paraíba State, between May and July 2018. Significant variables in the multiple analysis ( $p \leq 0.05$ ).

\begin{tabular}{cccc}
\hline & Variable & Odds ratio Cl (95\%) & P-value \\
\hline Risk factor & Origin (rural) & $2.93(1.18-7.92)$ & 0.02 \\
Protection factor & Vermifugated animal (yes) & $0.30(0.10-0.77)$ & 0.01 \\
& How the animal spends the night (Free) & $0.33(0.13-0.80)$ & 0.01 \\
\hline
\end{tabular}

The Kernel density estimator allowed us to determine the location for greater risk for the disease occurrence, and the areas with a higher concentration of cases are highlighted in red. These areas are situated in the North, Northwest, Northeast, central or urban area, and South of the municipality, with densities varying from 0.55 to 2.21 (Figure 2). The settlements situated in the Southeast region were not analyzed because access to these locations was not possible during the study period., while the endemic disease agents stated that there was an insignificant number of dogs in this area. 


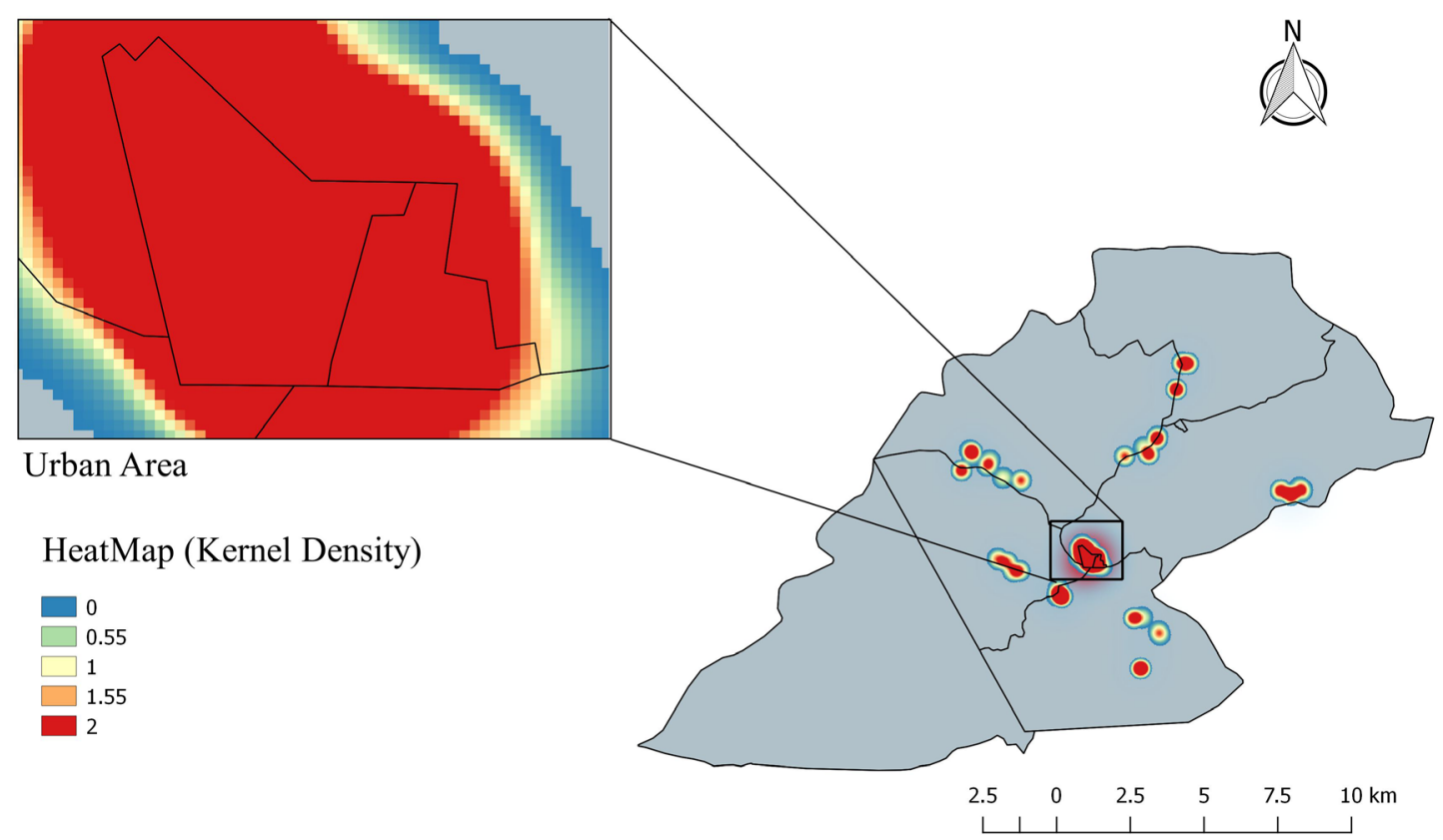

Figure 2. Kernel map showing areas with the greater distribution of canine visceral leishmaniasis cases in the municipality of Mãe D'Água, Semi-arid region of Paraíba State, 2018.

Using SaTScan, the clusters were calculated based on the relative risk. A primary cluster of significant risk $(p=0.010)$ was in the northern area of the urban zone (Figure 3 ), where dogs were 17.45 times more likely to become infected than those in other areas of the municipality. This cluster expanded to areas of vegetation without residencies in the limits of the municipality, except for a small portion in the Southeast extremity.

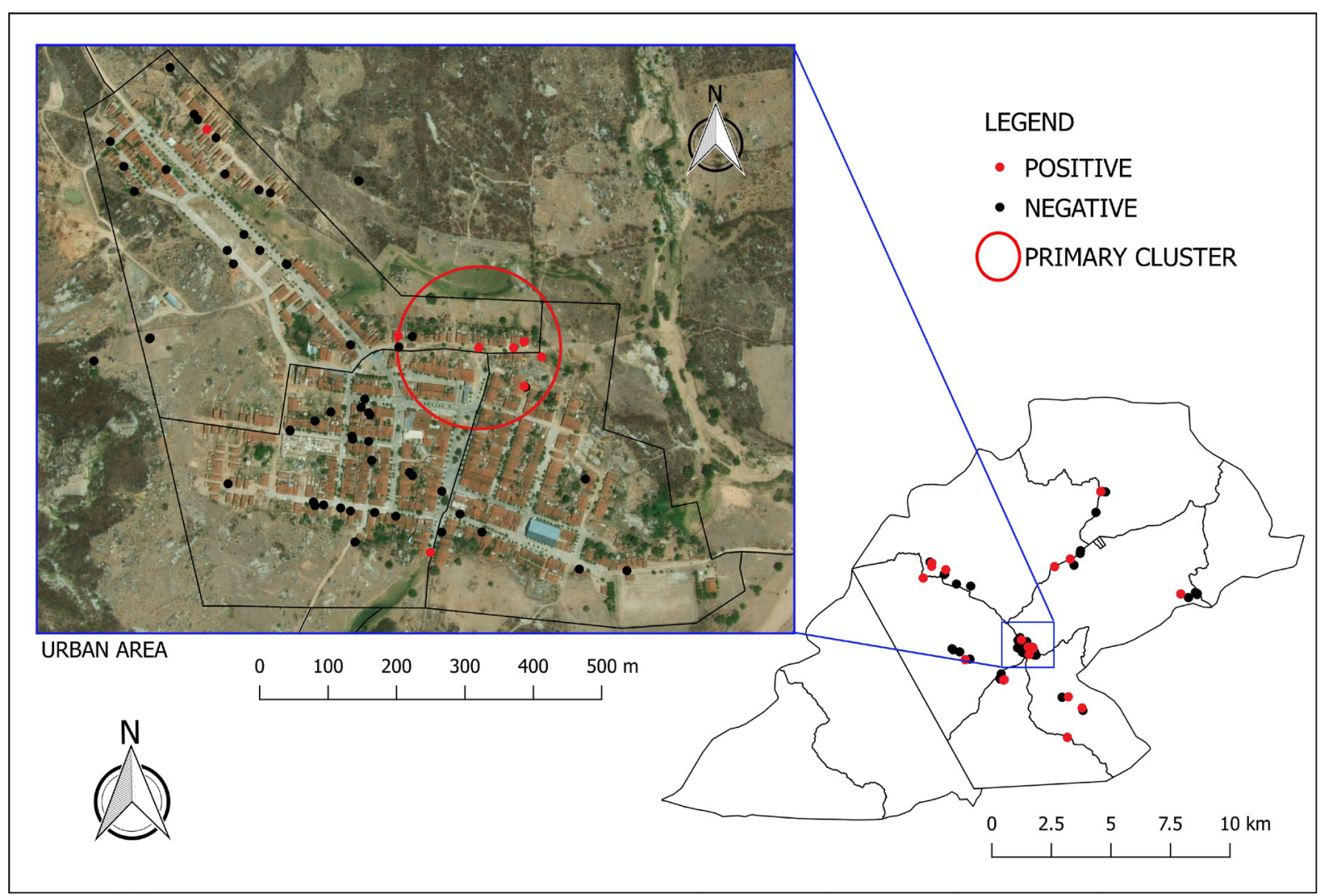

Figure 3. Satellite image showing the risk cluster for the occurrence of canine visceral leishmaniasis in the urban area of the municipality of Mãe D’Água, Paraíba, Brazil, 2018.Source: Google Earth. 


\section{Discussion}

Although the methodologies differ, the prevalence of canine Leishmania detected in this study is similar to that of several international studies conducted, e.g., in Iran (15.4\%) (Mahshid et al., 2014), Turkey (10.9\%) (Bakirci et al., 2016), and Brazil in Niterói-Rio de Janeiro (21.66\%) (Abrantes et al., 2018) as well as in other municipalities of the Sertão region of the Paraíba State, such as Cajazeiras (20\%), Uiraúna (16.3\%), Sousa (10.5\%), and Patos (7.2\%) (Silva et al., 2018). The highest or lowest prevalence may be attributed to the study region, the population characteristics, the statistical analysis used, and the sample size (Felipe et al., 2011; Wang et al., 2011; Brito et al., 2016; Silva et al., 2017b; Costa et al., 2018).

In the present study, the prevalence of canine Leishmania infection was higher in the rural area (26.6\%), and this variable was considered a risk factor for the occurrence of the disease, reinforcing the old dynamics of endemicity of visceral leishmaniasis in rural areas (Amóra et al., 2006). Although the disease has expanded to urbanized areas since 1950 (Figueiredo et al., 2012; Guimarães et al., 2017), this factor does not apply to the municipality studied, as the area is small and there is a close contact between the urban and rural areas.

The predominant vegetation in the municipality of Mãe D'Água is the Caatinga, still quite dense and preserved, which is a favorable environment for the survival of the disease vector, Lutzomyia longipalpis. It is important to mention that buildings in rural areas and the proximity to woodlands facilitate the contact of dogs and humans with the disease vectors in their natural habitat, thereby enabling the maintenance of the transmission cycle and increasing the chances of these animals becoming infected (Abrantes et al., 2018; Barbosa et al., 2010).

The occurrence of CVL is also related to social issues such as migration and disorderly construction of houses on the outskirts of cities, precarious basic sanitation and climatic changes resulting from deforestation, which allow the vector to reproduce and survive (Camargo et al., 2007; Gontijo \& Melo, 2004). The locations visited presented propitious environmental and social characteristics for the maintenance of the transmission cycle, such as the rearing of animals in the peridomicile and precarious sanitary conditions resulting from the organic matter produced.

In Mãe D'Água, 60\% of the guardians let their animals free during the night (loose, not fastened on a leash), and the category "free during the night/without a collar" was considered a protection factor, as these dogs were $67 \%$ more protected against the infection than those fastened on a leash at night during the study period. On the contrary, the prevalence of the zoonosis was higher in semi-domesticated dogs and those that spent the nights contained (Amóra et al., 2006). Our results showed that the dog's permanence in the peridomicile was an important risk factor for infection and was associated with higher contact incidences with vectors (Almeida et al., 2009).

It is believed that animals that spend the night fastened are restricted in a certain area, thus face a greater risk of being bitten by a vector. In contrast, an animal that is permitted to roam free during the night has higher mobility and can walk and sleep in different places, thereby decreasing its chances of becoming infected. Borges et al. (2009) observed that humans are infected more when the dogs are maintained indoors at night, which is the period that vector feed on hosts (from evening until dawn) (Felipe et al., 2011; Galati et al., 1996; Wang et al., 2011). The night also represents the time when most people and animals are in a restricted area inside their houses.

According to the Ministry of Health, prophylactic measures, such as vaccination and deworming, are essential to guarantee that animals are protected against diseases. In the present study, only $10 \%(7 / 70)$ of the dewormed dogs $(p=0.01)$ were seroreactant, which was indicative of protection against $L$. infantum infection, and may be associated with a better immune status of the evaluated dogs, as a result of greater care and wellbeing provided by the guardian (Brasil, 2003).

Spatial analysis is a tool that has been used in CVL epidemiological studies, with the intention of identifying priority areas and disease patterns as well as helping identify control measures for the zoonosis (Margonari et al., 2006). Using SaTScan ${ }$, a risk cluster $(p=0.010)$ was identified in the northern region of the urban area, with a light expansion to uninhabited areas and to a region of preserved woodland in the urban perimeter.

Most (96.4\%) of the urban residencies in the municipality of Mãe D'Água were located in public streets with afforestation, and only $15.2 \%$ were in areas with adequate urban features, such as drains, sidewalks, and paving (IBGE, 2020). The houses in the urban zone of the municipality were close to secondary vegetation with frequent accumulation of organic matter.

Rural and peripheral urban areas tend to have higher occurrence of $V L$ when in proximity to abundant vegetation (Cerbino Neto et al., 2009), which is proven to be the natural habitat of phlebotomine vectors, whose presence is indispensable for the maintenance of the transmission cycle; therefore, entomological monitoring is recommended in localities with active transmission (Borges et al., 2009). 
In this study, the disease was more prevalent in the rural area, but was dispersed all over the municipality, a fact that, according to Mestre et al. (2011) and Paulan et al. (2012), is related to the adaptation of the vector to the peridomicile conditions. Such localities are often characterized by a lack of infrastructure or anthropogenic activities, or by the migration of dogs and infected individuals.

The pattern of active transmission of Leishmania in Mãe D'Água was more prevalent in the rural area. As human VL cases were recently reported, the adoption of immediate control measures, such as the use of repellent collars, control of vectors in household environments and in the peridomicile with insecticides, removal of organic matter from the peridomicile, and refrainment of rearing domestic animals close to the domicile, are recommended. Additionally, these measures need to be implemented in the urban area to prevent the expansion of the disease and the occurrence of human cases in the risk zone.

\section{References}

Abrantes TR, Werneck GL, Almeida AS, Figueiredo FB. Fatores ambientais associados à ocorrência de leishmaniose visceral canina em uma área de recente introdução da doença no Estado do Rio de Janeiro, Brasil. Cad Saude Publica 2018; 34(1): e00021117. http://dx.doi.org/10.1590/0102-311x00021117. PMid:29412315.

Agência Executiva de Gestão das Águas - AESA. Meteorologia [online]. 2019 [cited 2019 Aug 28]. Available from: <http://www. aesa.pb.gov.br/aesa-website/meteorologia-chuvas/>.

Almeida ABPF, Faria RP, Pimentel MFA, Dahroug MAA, Turbino NCMR, Sousa VRF. Inquérito soroepidemiológico de leishmaniose canina em áreas endêmicas de Cuiabá, Estado de Mato Grosso. Rev Soc Bras Med Trop 2009; 42(2): 156-159. http://dx.doi. org/10.1590/S0037-86822009000200012. PMid:19448933.

Amóra SSA, Santos MJP, Alves ND, Costa SCG, Calabrese KS, Monteiro AJ, et al. Fatores relacionados com a positividade de cães para leishmaniose visceral em área endêmica do Estado do Rio Grande do Norte, Brasil. Cienc Rural 2006; 36(6): 1854-1859. http://dx.doi.org/10.1590/S0103-84782006000600029.

Ashford RW. Leishmaniasis reservoirs and their significance in control. Clin Dermatol 1996; 14(5): 523-532. https://doi. org/10.1016/0738-081x(96)00041-7.

Bakirci S, Bilgiç HB, Köse O, Aksulu A, Hacilarlioğlu S, Erdoğan H, et al. Molecular and seroprevalence of canine visceral leishmaniasis in West Anatolia, Turkey. TurkJ Vet Anim Sci 2016; 40: 637-644. http://dx.doi.org/10.3906/vet-1508-73.

Barbosa DS, Rocha AL, Santana AA, Souza CSF, Dias RA, Costa-Júnior LM, et al. Soroprevalência e variáveis epidemiológicas associadas à leishmaniose visceral canina em área endêmica no município de São Luís, Maranhão, Brasil. Cienc Anim Bras 2010; 11(3): 653-659. http://dx.doi.org/10.5216/cab.v11i3.5933.

Beltrão BA, Morais F, Mascarenhas JC, Miranda JLF, Souza LC Jr, Mendes VA. Serviço Geológico do Brasil (org.). Projeto cadastro de fontes de abastecimento por água subterrânea estado de Paraíba: Diagnóstico do município de Mãe d'Água. Recife: CPRM/PRODEEM; 2005.

Borges BKA, Silva JA, Haddad JPA, Moreira EC, Magalhães DF, Ribeiro LML, et al. Animal presence and the risk for transmission of visceral leishmaniasis in Belo Horizonte, Brazil. Arq Bras Med Vet Zootec 2009; 61(5): 1035-1043. http://dx.doi.org/10.1590/ s0102-09352009000500004.

Brito FG, Langoni H, Silva RC, Rotondano TEF, Melo MA, Paz GS. Canine visceral leishmaniasis in the Northeast Region of Brazil. J Venom Anim Toxins Incl Trop Dis 2016; 22(1): 15. http://dx.doi.org/10.1186/s40409-016-0069-4. PMid:27076813.

Bruce P, Bruce A. Practical Statistics for Data Scientists. Califórnia: O’Reilly Media; 2017.

Camargo JB, Troncarelli MZ, Ribeiro MG, Langoni H. Leishmaniose visceral canina: aspectos de saúde pública e controle. ClínVet 2007; 71: 86-92.

Cerbino Neto J, Werneck GL, Costa CHN. Factors associated with the incidence of urban visceral leishmaniasis: an ecological study in Teresina, Piauí State, Brazil. Cad Saude Publica 2009; 25(7): 1543-1551. http://dx.doi.org/10.1590/S0102-311X2009000700012. PMid:19578575.

Cohen C, Corazza F, De Mol P, Brasseur D. Leishmaniasis acquired in Belgium. Lancet 1991; 338(8759): 128. http://dx.doi. org/10.1016/0140-6736(91)90129-D. PMid:1676463.

Costa DNCC, Bermudi PMM, Rodas LAC, Nunes CM, Hiramoto RM, Tolezano JE, et al. Human visceral leishmaniasis and relationship with vector and canine control measures. Rev Saude Publica 2018; 52: 92. http://dx.doi.org/10.11606/S1518-8787.2018052000381. PMid:30484481.

Fávero LPL, Belfiore PP, Silva FL, Chan BL. Análise de dados: modelagem multivariada para tomada de decisões. Rio de Janeiro: Elsevier; 2009. 
Felipe IMA, Aquino DMC, Kuppinger O, Santos MDC, Rangel MES, Barbosa DS, et al. Leishmania infection in humans, dogs and sandflies in a visceral leishmaniasis endemic area in Maranhão, Brazil. Mem Inst Oswaldo Cruz 2011; 106(2): 207-211. http:// dx.doi.org/10.1590/S0074-02762011000200015. PMid:21537682.

Fernandes ARF, Costa DF, Pimenta CLRM, Araújo KN, Silva RBS, Melo MA, et al. Occurrence and risk factors of zoonoses in dogs and guardians in Sertão, Paraíba state, northeastern Brazil. Semina: Ciênc Agrár 2018; 39(3): 1057-1066. http://dx.doi. org/10.5433/1679-0359.2018v39n3p1057.

Figueiredo ABF, Werneck GL, Cruz MSP, Silva JP, Almeida AS. Uso e cobertura do solo e prevalência de leishmaniose visceral canina em Teresina, Piauí, Brasil: uma abordagem utilizando sensoriamento remoto orbital. Cad Saude Publica 2017; 33(10): e00093516. http://dx.doi.org/10.1590/0102-311x00093516. PMid:29116318.

Figueiredo FB, Lima FEF Jr, Tomi JE, Indá MC, Corrêa GLB, Madeira MF. Leishmaniose Visceral Canina: dois casos autóctones no município de Florianópolis, estado de Santa Catarina. Acta Sci Vet 2012; 40(1): 1026.

Galati EAB, Nunes VLB, Dorval MEC, Oshiro ET, Cristaldo G, Espíndola MA, et al. Estudo dos flebotomíneos (Diptera, Pychodidae), em área de leishmaniose tegumentar, no Estado de Mato Grosso do Sul, Brasil. Rev Saude Publica 1996; 30(2): 115-128. http:// dx.doi.org/10.1590/S0034-89101996000200002. PMid:9077009.

Gatrell AC, Bailey TC, Diggle PJ, Rowlingson BS. Spatial point pattern analysis and its application in geographical epidemiology. Trans Inst Br Geogr 1996; 21(1): 256-274. http://dx.doi.org/10.2307/622936.

Gontijo CMF, Melo MN. Visceral Leishmaniasis in Brazil: current status, challenges and prospects. Rev Bras Epidemio/ 2004; 7(3): 338-349. http://dx.doi.org/10.1590/S1415-790X2004000300011.

Guimarães A, Raimundo JM, Santos HD, Machado RZ, Baldani CD. Serosurvey for canine visceral leishmaniasis in rural and urban areas of the Brazilian Legal Amazon. Braz J Infect Dis 2017; 21(2): 207-208. http://dx.doi.org/10.1016/j.bjid.2016.10.013. PMid:27986490.

Hosmer DW, Lemeshow WS. Applied Logistic Regression. 2nd ed. New York: John Wiley and Sons; 2000. http://dx.doi. org/10.1002/0471722146.

Instituto Brasileiro de Geografia e Estatística - IBGE. Cidades e estados do Brasil [online]. Rio de Janeiro: IBGE; 2020 [cited 2020 Jan 20]. Available from: https://cidades.ibge.gov.br/brasil/pb/mae-dagua/panorama

James G, Witten D, Hastie T, Tibshirani R. An Introduction to Statistical Learning: With Applications in R. New York: Springer Publishing Company, Incorporated; 2014.

Lainson R, Rangel EF. Lutzomyia longipalpis and the eco-epidemiology of American visceral leishmaniasis, with particular reference to Brazil: a review. Mem Inst Oswaldo Cruz 2005; 100(8): 811-827. http://dx.doi.org/10.1590/S0074-02762005000800001. PMid:16444411.

Levine N. CrimeStat: A Spatial Statistical Program for the Analysis of Crime Incidents. In: Shekhar S, Xiong H, Zhou X, editors. Encyclopedia of GIS. Cham: Springer; 2017. http://dx.doi.org/10.1007/978-3-319-17885-1_229

Mahshid M, Baharak A, Iraj S, Sina K, Javad K, Mehdi B. Seroprevalence of canine visceral leishmaniasis in southeast of Iran. $J$ Parasit Dis 2014; 38(2): 218-222. http://dx.doi.org/10.1007/s12639-012-0226-9. PMid:24808656.

Margonari C, Freitas CR, Ribeiro RC, Moura ACM, Timbó M, Gripp AH, et al. Epidemiology of visceral leishmaniasis through spatial analysis, in Belo Horizonte municipality, state of Minas Gerais, Brazil. Mem Inst Oswaldo Cruz 2006; 101(1): 31-38. http://dx.doi. org/10.1590/S0074-02762006000100007. PMid:16699707.

Mestre GLC, Ribeiro ALM, Miyazaki RD, Rodrigues JSV, de Almeida ABPF, Sousa VRF, et al. Phlebotomine sand flies and canine infection in areas of human visceral leishmaniasis, Cuiabá, Mato Grosso. Rev Bras Parasitol Vet 2011; 20(3): 228-234. http://dx.doi. org/10.1590/S1984-29612011000300010. PMid:21961754.

Brasil. Ministério da Saúde. Departamento de Vigilância Epidemiológica. Manual de vigilância e controle da leishmaniose visceral. [online]. Brasília; 2003. [cited 2018 Nov 12]. Available from: http://bvsms.saude.gov.br/bvs/publicacoes/manual_vigilancia_ prevencao_controle_zoonoses.pdf.

Brasil. Ministério da Saúde. Departamento de Vigilância Epidemiológica. Manual de Vigilância e Controle da Leishmaniose Visceral [online]. Brasília; 2006. [cited 2018 Nov 20]. Available from: http://bvsms.saude.gov.br/bvs/publicacoes/manual_vigilancia_ controle_leishmaniose_visceral.pdf.

Brasil. Ministério da Saúde. Departamento de Vigilância Epidemiológica. Leishmaniose visceral: Recomendações clínicas para a redução da letalidade [online]. Brasília; 2011. [cited 2018 Dec 20]. Available from: http://bvsms.saude.gov.br/bvs/publicacoes/ leishmaniose_visceral_reducao_letalidade.pdf

Brasil. Ministério da Saúde, Departamento de Vigilância Epidemiológica. Manual de vigilância prevenção e controle de zoonoses [online]. Brasília; 2016. [cited 2018 Nov 20]. Available from: <http://bvsms.saude.gov.br/bvs/publicacoes/manual_vigilancia_ prevencao_controle_zoonoses.pdf>. 
Missawa NA, Lima GBM. Distribuição espacial de Lutzomyia longipalpis (Lutz \& Neiva, 1912) e Lutzomyia cruzi (Mangabeira, 1938) no estado de Mato Grosso. Rev Soc Bras Med Trop 2006; 39(4): 337-340. http://dx.doi.org/10.1590/S0037-86822006000400004. PMid:17119747.

Paulan SC, Silva HR, Lima EACF, Flores EF, Tachibana VM, Kanda CZ, et al. Spatial distribution of canine Visceral Leishmaniasis in Ilha Solteira, São Paulo, Brazil. Eng Agric 2012; 32(4): 765-774. http://dx.doi.org/10.1590/S0100-69162012000400016.

Rodrigues ACM, Melo ACFL, Júnior ADS, Franco SO, Rondon FCM, Bevilaqua CML. Epidemiology of visceral leishmaniasis in Fortaleza, Ceará, Brazil. Pesq Vet Bras 2017; 37(10): 1119-1124. http://dx.doi.org/10.1590/s0100-736x2017001000013.

Savani ES, Schimonsky Bv B, Camargo MC, D'auria SR. Vigilância de leishmaniose visceral americana em cães de área não endêmica, São Paulo. Rev Saude Publica 2003; 37(2): 260-262. http://dx.doi.org/10.1590/S0034-89102003000200016. PMid:12700851.

Silva JMC, Leal IR, Tabarelli M. Caatinga: The largest tropical dry forest region in South America. Cham, Switzerland: Springer; 2017a. http://dx.doi.org/10.1007/978-3-319-68339-3

Silva JD, Melo DHM, Costa JAG, Costa DF, Silva RBS, Melo MA, et al. Visceral leishmaniasis in dogs from rural settlements. Pesq Vet Bras 2017b; 37(11): 1292-1298. http://dx.doi.org/10.1590/s0100-736x2017001100016.

Silva RBS, Porto ML, Barbosa WO, Souza HC, Marques NFSP, Azevedo SS, et al. Seroprevalence and risk factors associated with canine visceral leishmaniasis in the State of Paraíba, Brazil. Rev Soc Bras Med Trop 2018; 51(5): 683-688. http://dx.doi. org/10.1590/0037-8682-0429-2017. PMid:30304279.

Sistema de Informação de Agravos de Notificação - SINAN. Casos notificados de leishmaniose visceral na Paraíba [online]. Brasília: SINAN; 2019 [cited 2019 Jan 18]. Available from: http://tabnet.datasus.gov.br/cgi/tabcgi.exe?sinannet/cnv/leishvPB.def.

Sousa NA, Linhares CB, Pires FGB, Teixeira TC, Lima JS, Nascimento MLO. Epidemiological profile of cases of visceral leishmaniasis in Sobral, Ceará, Brazil, from 2011 to 2015. SANARE -. Rev Políticas Públicas 2018; 17(1): 51-57.

Thrusfield MV. Veterinary epidemiology. Oxford: Blackwell Science; 2007.

Wang J-Y, Ha Y, Gao C-H, Wang Y, Yang Y-T, Chen H-T. The prevalence of canine Leishmania infantum infection in western China detected by PCR and serological tests. Parasit Vectors 2011; 4(1): 69. http://dx.doi.org/10.1186/1756-3305-4-69. PMid:21554677.

Werneck GL. Visceral leishmaniasis in Brazil: rationale and concerns related to reservoir control. Rev Saude Publica 2014; 48(5): 851-856. http://dx.doi.org/10.1590/S0034-8910.2014048005615. PMid:25372177.

World Health Organization - WHO. Strategic framework for leishmaniasis control in the WHO European Region $2014-2020$ [online]. Genebra: WHO; 2014 [cited 2018 Nov 06]. Available from: https://www.euro.who.int/_data/assets/pdf_file/0008/239426/ outlining-a-strategic-framework-on-leishmaniasis-control.pdf

World Health Organization - WHO. Leishmaniasis [online]. Genebra: WHO; 2018 [cited 2019 Mar 15]. Available from: http://www. who.int/leishmaniasis/en

Zar JH. Biostatistical analysis. 4th ed. New Jersey: Prentice-Hall; 1999. 